\title{
Voluntary action, territory and timing: the Council of Social Service for Wales, periodisation and the new historiography of the 'British Welfare State', 1919-1980.
}

Daniel Wincott (Lead Author)*, Paul Chaney** and Christala Sophocleous***

*Blackwell Professor of Law and Society, Cardiff University School of Law and Politics, Wales Governance Centre; Co-Investigator, WISERD

**Professor of Policy and Politics, Cardiff University School of Social Sciences; Co-Director of WISERD

***Research Associate, WISERD; Cardiff University School of Social Sciences

The research on which this article is based was undertaken within WISERD/Civil Society Research Centre funded by the ESRC (ES/L009099/1) and WISERD Civil Society: Changing perspectives on Civic Stratification and Civil Repair (ES/S012435/1) grants; additionally, Daniel Wincott's contribution was supported by the Between two Unions (ES/P009441/1) grant.

Competing interests: The authors declare none.

Abstract:

This article analyses the development of the Council of Social Service for Wales during what is often called the Golden Age of the Welfare State. Recovering the neglected history of the peak organisation for voluntary social service in Wales adds to our understanding of the histories of social policy and postwar Wales. The article addresses social policy from a doubly peripheral perspective - it attends to a territorial periphery of the UK State while voluntary action can be left at the margins of Welfare State analysis. From this perspective we hope to cast new light on the historiography of the 'British Welfare State' 
1. Introduction

A conventional wisdom has helped shape public debate and scholarly analysis of the welfare state. Something like a welfare state 'imaginary' (Anderson 1983; Wincott 2020), developed around the core idea of a thirty -year post-war welfare state 'golden age' (critiqued, comparatively, in Wincott 2013). Two features of this putatively 'halcyon era' (Hills, 1990: 1) loom large, both related to 'nationalisation': 1) growth of statutory or public provision and displacement of non-state (especially voluntary/charitable) organisations and 2) replacement of local services by pannation-state provision. Like most widely-held conventional views, the 'golden age' captures important aspects of welfare state history (in the UK and elsewhere), including the 'nationalisation' of local and voluntary hospitals into the National Health Service. If contrarian dismissal of the 'golden age' is unhelpful, the frame does require close scrutiny (see Hills 1990 emphasizing successes after state welfare's putatively halcyon days).

Here, we interrogate the standard analysis of golden age British welfare 'nationalisation' from a distinctive peripheral perspective. The territorial focus of our analysis is Wales. We analyse the historic development of its peak membership organisation for voluntary organisations, today known as the Wales Council for Voluntary Action (WCVA). Precursors organisations - territorial 'Councils of Social Service' (CsSS) - consolidated as a UK-wide network after the Second World War. By 1947, that is, the London-based National Council of Social Service (NCSS, founded 1919) had been joined by Councils in Northern Ireland, Scotland and Wales (see Table One, below). This structure - an England-focused organisation that presented itself as 'national', flanked by distinct Councils for Northern Ireland, Scotland and Wales - eerily prefigured the twenty-first century structure of UK political devolution.

Other Welsh names - Lloyd George and Bevan - sound loudly through British welfare history; those associated with the Welsh social service council have left barely an echo. Wales integrated with England earlier and more fully than Ireland or Scotland. It lacks a distinct legal jurisdiction and is marked by comparatively weak civil society (Paterson and Wyn Jones 1999; Royles 2007; Day 2002). Perhaps as a consequence, WCVA's role in devolved governance is particularly prominent today. How, in the apparently inhospitable environment of postwar Wales, was a distinctive (sub-state) national voluntary social service council created? How did it survive? Here, we use a key (if inevitably partial) evidential source to trace that history.

The article has broader conceptual ambitions, beyond its empirical analysis, picking up themes and concepts from recently historical and institutionalist analyses. Edgerton (2018) unsettles the standard historiography of twentieth-century Britain, including over the welfare state. He emphasizes discontinuities: the 'British nation's' emergence from Edwardian globalism; its subsequence collapse as Thatcherites reglobalised the UK economy. Although Edgerton's periodisation broadly follows the standard welfare state story's temporal arc, his focus is quite different: on imports, exports and warfare capacity. Edgerton doubts 'whether Keynesianism or welfarism were at the centre of politics, let alone state practices' (2018: 378).

The conventional framework also tends to squeeze diverse strands of welfare policy/provision, each with a potentially distinctive rhythm, into a singular narrative. 
Institutionalist concepts of policy drift, conversion and layering (Hacker 2005; Streek and Thelen 2005; Hacker, Pierson and Thelen 2013) offer a gradualist critique of assumed continuities. Attending to voluntary action in Wales troubles the postwar welfare state's homogenised image, potentially unsettling the standard periodisation. For social services in Wales, British policy, local government and voluntary action are layered (Hacker 2005) and interwoven.

Our territorial (sub-state national) analysis raises questions about methodological nationalism (or national-statism) and the welfare state (Jeffery and Wincott 2010). A focus on organised voluntarism qualifies conventional assumptions about British postwar 'statism' (Crosland 1952).

As developed around the welfare state, the standard golden age periodisation (Wincott 2013) can be misleading. Informed by these perspectives, we aim to add interactions between territoriality and methodological national-statism, timing and periodisation, and the balance of voluntary-statutory provision to debate about the place of social policy in postwar British history. These issues each challenge the conventional welfare state narrative; their interaction begs wider historiographical questions. Following a brief history of the UK's CsSS in section two, we take these conceptual themes up in section three.

The article then turns to the Welsh Council's history, as recorded in its annual reports. These reports provide a rich, if inevitably one-sided, resource for recovering the Council's history. Previously neglected by analysts of voluntary action, of the welfare state and of Welsh history, we use them to trace a history of the Welsh Council. Its initial incarnation in South Wales was a response to the impact of the Great Depression, the Council become a national organisation for postwar and sustained a role throughout the welfare state's putatively halcyon days. Our territorial analysis suggests that the complex layering (Hacker 2005) of voluntary and state social action requires further attention within the temporalities of UK welfare history.

Although they remain overshadowed by Britain or UK-wide studies, this analysis add to a growing body of social policy research on the UK's sub-state nations and jurisdictions. Territorially precise analysis tends to cluster in particular sub-fields, and often focuses specifically on England. The Journal of Social Policy has carried Kendall et al (2018), Checkland et al (2012), Sheaff (2009), Propper et al (2006), Stevens et al (2011) and Powell and Miller (2014) on English health policy. A strong England-oriented literature addresses marketisation, social enterprise and the thirdsector (Hill et al. 2012; Alcock 2010), with a some pan-UK studies of devolution (Alcock 2012). Drawing on political science, a specialist literature considers devolution and social policy UK-wide (Birrill 2009; Keating 2019), in Scotland (Mooney and Scott 2005; McEwen 2006) and Northern Ireland (Simpson 2017), although without a strong focus on voluntary action. Even in comparison to the other parts of the UK, relatively little research is devoted to social policy in Wales. Still less attention paid to WCVA, although specialist Welsh history (Johnes 2012) and civil society (Royles 2007) monographs touch on its pivotal role after devolution.

Before 1998 and political devolution analysts rarely asked territorial questions. Official histories of NCSS (Brasnett 1969) and the National Council for Voluntary Organisations (NCVO - Davis Smith 2019) cover this period. Equivalent attention 
has not been paid to its counterparts in Northern Ireland, Scotland and Wales. Even specialist contemporary histories and sociologies of Wales neglect WCVA's

predecessor institutions (Davies 2007; Johnes 2012; Day 2002; Royles 2007).

\section{Councils of Social Service}

That voluntary action held an enduring place in postwar social service provision is, now, well established (Brasnett 1969; Brenton 1985; Finlayson 1994; Davis Smith 2019). 'Statism' (Crosland's initial (1952) label for Attlee's achievements) never eradicated voluntarism. Yet mainstream welfare state analysis neglects NCSS, and largely ignore its present-day successor, NCVO. Here, we also briefly outline a history of its previously invisible counterparts in Wales, Northern Ireland and Scotland.

As the twentieth century began, a 'wide variety of voluntary groups' committed to 'social work' co-existed locally and nationally. Hampstead, in London, was exemplary. There the 'Associated Agencies' were founded in 1902. After 'study circles of social workers were formed in churches, clubs and institutions.... It became clear to them that something was needed to bring all the agencies serving the people of Hampstead together - a council of social welfare' (Brasnett, 1969: 8). By 1919 this 'simple' idea had been translated to the 'national' level. The 'rich and varied pattern of voluntary societies which is the distinctive feature of English social life is worth preserving; ... it could be best preserved if the diverse agencies were to come together into some form of federation or council to eliminate confusion and overlapping; and to work together as partners with the nearly developing statutory services' (Brasnett 1969: 19).

NCSS was designed as an umbrella for local groups. Also, it encouraged, supported and sometimes initiated the formation of new bodies. The timing of its creation was propitious. Despite some tensions with the older Charity Organisation Society, the new NCSS allowed voluntary social service providers to distance themselves from Victorian ideas about charity. They could embrace working with the statutory sector, while carving out a new space for voluntarism in changing social and political circumstances.

The role of these Councils has, of course, changed over the century since the NCSS was founded. Their original roles - convening a forum for voluntary organisations/action; second, supporting/building capacity - remain important. As well as supporting and providing services to voluntary organisations, at certain times Councils have delivered services directly to the public. At least until the mid-1970s, the Welsh Council had close relations with local authorities; across England a network of local councils under NCSS maintained similar contacts. Through most of that period any boundary between local authorities and voluntary action was, arguably, very blurry: arguably party politics had not yet been fully mobilised at local level. NCSS always had links to Whitehall and Westminster. The Welsh Office, a UK Government department, was established in 1965; by the mid-1970s it was the Welsh Council's key interlocutor. Today, representing voluntary organisations/action to the UK's four central governments is a key role for each territorial council.

[Table One about here] 
The Great Depression triggered a wave of voluntary action. Its impact in the industrial South Wales Valleys caused concern among prominent figures in Welsh society. The Davies sisters hosted gatherings at Gregynog, their mid-Wales country house, in 1932 and 1933. SWMCSS was formed in 1934with support from NCSS. Sir Percy Watkins, who retired from the Welsh Department to the Board of Education in 1933, played a key role as NCSS Regional Officer for Wales (Brasnett 1969: 142). For similar reasons, in 1938 NICSS was created in Northern Ireland.

SWMCSS supported the creation of local clubs (typically separately for women and men) in areas of high unemployment. Criticised by some on the left, these clubs aimed at maintaining social relationships, partly to prevent men from becoming 'unemployable'. They focused on 'useful' activities for members and their families (furniture-making, cobbling, cooking) and also constructed local amenities, such as sports fields.

A Scottish Council (SCSS) was created during the Second World War. The CsSS structure now had a presence in each UK nation and jurisdiction. The Councils took on new roles, such as developing a Citizens Advice Bureaux (CABx) network intended to provide local support to a population facing the wartime pressures. This development prefigured a later role: subsequently the Councils nurtured new forms of voluntary action, including for older people, young people and people with disabilities.

From 1945 until the 1970s NCSS served as a federal-type body for a range of local groups. It also organised specialised committees on a variety of particular themes. The Scottish, Welsh and Northern Irish Councils were 'autonomous, self-governing bodies' and NCSS members 'in recognition of the latter's special role in formulating policies that have significance for the whole of the United Kingdom and in presenting these policies to central government' (Brasnett 1969: 143). Between 1970 and 1980, a series of organisations gained independence from NCSS, including Age Concern, the $\mathrm{CAB}$, the National Association of Women's Clubs and National Council for Voluntary Youth Services (Davis Smith 2019: 147-149). This process of NCSS centralisation meant the Council ceased to see itself as a 'federation of varied autonomous associated bodies' (Davis Smith 2019: 146) although member organisations could still contribute to national policy.

\section{Hiding history in plain sight? Welfare Statism and voluntarism, territory and time}

The idea that Labour's postwar approach to social services was basically statist (Crosland 1952) remains tenacious: at mid-century any questions about 'by whom' public services should be provided 'appeared ... to have been resolved' (Ansell and Lindvall 2020: 269). Despite a valuable specialist literature on voluntarism and the welfare state, this assumption remains strong in welfare state research, which also tends towards 'methodological national-statism' (Chernilo 2007; Jeffery and Wincott 2010). That is, it often assumes an equivalence between nations and states, treating the national state as the natural scale in social, political and economic life/analysis. Assuming that the welfare state is, essentially, a national-state-wide, statutory phenomenon, in effect, hides enduring sub-state and voluntary dimensions in plain sight. 
Temporal frames - including golden age-type periodisations - are equally easily naturalised (Lazar 2019; Wincott 2013). Periodisation - the division of history into blocs of time - is ubiquitous and arguably unavoidable. It is too often treated as implicit in, or emerging naturally from, history. Instead, periodisation can be used as an explicit methodological tool, as a way of handling temporality. In general, interactions with voluntarism, territoriality and time raise broad historiographical and methodological questions for social policy analysis.

Some studies hint that voluntary social action has its own temporality, distinct from the welfare state's putative golden age. Finlayson's (1994) overarching history of twentieth-century voluntary social action offered a distinctive set of time periods, but the standard periodisation for state welfare. Brenton partly followed the conventional periodisation (dating the 'welfare state' from Labour's postwar reforms), while pointing in a different direction for local government and changing voluntary action dynamics (1985: 22-24, 23, 36-56). Both analysts imply that statutory and voluntary provision follow distinctive temporal rhythms, while also interacting.

Analysts of voluntary social service provision have largely neglected territoriality. The official fiftieth anniversary analysis of NCSS (Brasnett 1969) mentioned the territorial councils briefly; Davis Smith's centenary history (2019) focused tightly on the NCVO. Though based, respectively, at universities in Wales and Scotland, Brenton (1985) and Finlayson (1994) both framed their studies as 'British': Brenton ignored the territorial CsSS completely; Finlayson mentioned SCVO briefly as exemplifying 'local' voluntary action.

The territorial and temporal aspects of our analysis need to be developed, in general methodological terms, with care. Postwar British social reforms were framed as 'national' (note the 'official names' of the National Health Service, National Insurance and National Assistance - Ferrera 2005: 46). Nothing here is meant to diminish that moment of 'national' framing. Equally, the meaning of the 'nation' was, at the time largely implicit or taken-for-granted. Consider TH Marshall's treatment of the 'national' in his postwar text on citizenship: it was 'by definition' the territorial frame for the 'citizenship whose history I wish to trace' ([1950] 1992: 9, also 25). Beyond the transcendence of a prior patchwork of local provision, Marshall did little explicitly to flesh it out: on interrogation this 'national' citizenship provided the welfare state with uncertain foundations. First, Marshall's argument did not pivot on the welfare state concept; that term appears only once in the essay ([1950] 1992: 25]). Second, the 'national' vision was cloaked in the trans-territorial frame of 'universalism' ([1950] 1992: 28, 31). 'Universalism' came to play a central conceptual role in subsequent social policy analysis, while the nation faded from view. Finally, Marshall's imagined 'nation' was England ([1950] 1992: 18) not Great Britain or the United Kingdom.

Following Marshall, a general assumption came to be made: the welfare state was national; territorial questions were, consequently, rarely asked (Keating 2009). A recent pathbreaking comparative analysis of public service development - Ansell's and Lindvall's Inward Conquest (2020) - is illustrative. They show how the temporal entwines with the territorial in the rise of central state control across the world's wealthiest countries. Yet in treating UK as centralized and unitary, they attend to England and largely ignore its other national territories. Studying 
centralisation over the century or so up to 1939, their powerful general analysis selfconsciously sets the stage for the postwar development of transfer-focused social policies. In doing so, however, they draw our gaze away from contemporaneous issues around territoriality, voluntarism and services.

Since the turn of the twenty-first century important correctives have emerged to the methodological national-statism of welfare state analysis, both around devolution (Mooney and Scott 2005; McEwen 2006; Birrell 2009; Keating 2009; Simpson 2017) and comparatively (Ferrera 2005). Often, however, these analyses strive to squeeze territorial effects into the dominant periodisation. Although focused on territoriality, Ferrera's (2005) pathbreaking analysis describes an arc of national-centralisation from mid-century through the postwar decades. Like Ansell and Lindvall (2020) for the preceding century, while Ferrera (2005) captures important dimensions of social policy we shall see that his analysis occludes important aspects of welfare history.

\section{Councils of Social Service, 1946-1970s: dis/continuity}

The postwar history of CsSS and welfare policy can be divided into two phases: mid1940 s to early $1960 s ; 1960$ s and 1970s. In the 1940 s and 50 os neither main political party was actively hostile to voluntary action (on Attlee's administration see Deakin and Davis Smith 2011). During a House of Lords debate on 22 June 1949 over 'Voluntary Action and Social Progress' - Labour's Lord Pakenham said that 'beyond any shadow of misunderstanding ... democracy without voluntary exertion and voluntary idealism loses its soul' (see Brenton 1985: 22). In practice, statutory expansion did not wholly drive out voluntarism.

After Labour's initial wave of social legislation, rather than expanding social provision, government consolidated it during the 1950s. More than initiating a new dynamic, Labour's postwar social legislation may have completed a previous wave of reforms. Local authority welfare services also 'saw few significant developments' during these 15 years. They had a 'low priority ... limited organisational and financial resources and ... [showed] very slow development of professional training and standards of care' (Brenton, 1985: 23). For voluntary action the watchwords were 'marking time'. Not much new happened for social services during these years across central, local and voluntary action.

The voluntary sector was caught in a wave of change during the 1960s (Brenton, 1985). The national/territorial CsSS faced distinct challenges and responded in a variety of ways. New voluntary 'organisations, groups and movements ... grew up in the 1960 s and 1970s' as 'the by-product of the public sector welfare system', not its antithesis (Brenton 1985: 36, generally 36-56). Although new organisations challenged the position of NCSS (Smith 2019) in the 1960s, CSSWM faced fewer novel groups in Wales. A long saga of local government restructuring began from the late 1950 s and became linked to increasing emphasis on personal social services. It proved particularly important in Wales. Taken together, from the early 1960s these changes contributed to full emergence in public discourse of the welfare state label. The CSSWM first used the term in an Annual Report in 1961 (1960-61: 5).

Establishing and consolidating the institutional framework: the state, welfare and the CsSS, 1946-1960 
While NICSS and SCSS wholly covered their respective territories, until after the Second World War SWMCSS was not a fully 'national' body. It did, though, have a clear national identity: 'Wales should be thought of as the unity and entity that it is' (SWMCSS 1940: 9). In the 1930s, where bottom-up voluntary social service initiatives were lacking in Wales, NCSS filled the gap. It appointed a Regional Officer for North Wales shortly before the war; another officer then was seconded for Denbighshire and Flintshire (SWMCSS, 1940: 9), providing a CSS presence right across Wales (SWMCSS, 1940: 9). SWMCSS helped to create network of wartime Citizen's Advice Bureaux (CABx), financed by the Ministry of Health.

On 9 December 1946 the Welsh Council received a licence from the Board of Trade. The new CSSWM subsumed both SWMCSS and the North Wales Regional Officers. The process of becoming a fully national body for Wales was not entirely smooth. In 1945-46 NCSS reported:

"The formation of a Council for Wales has taken rather longer than was anticipated, but it is now probable that one will be in operation by the end of March, 1947. The National Council welcomes this move and will do its utmost to help the new Council to become firmly established. There is a great need in Wales, both in town and country, for an efficient, forward looking, coordinating social service agency which will cover the whole Principality. Nowhere are there more formidable difficulties of geography, finance, and organisation to be overcome." (Quoted in CSSWM Interim Report, 1947: 7).

CSSWM thanked '...the National Council for its deep concern with the work in Wales.' (Interim Report, 1947: 6).

The Welsh Council had a delicate relationship with NCSS. Its first full Annual Report called the National Council its 'parent body', with CSSWM attributing its own formation to NCSS. Equally, the Welsh Council regarded itself as 'an independent body' (Annual Report 1947-48: 11-12). It expressed gratitude 'for the opportunity to supply a Regional Service to the National Council' and praised the 'parental interest' of NCSS 'and its 'unfailing desire to understand Wales, with its special and traditional problems ... and ... sense of championship that does not fall short of financial help whenever possible' (CSSSWM, Annual Report 1947-48: 12).

On becoming an all-Wales body, CSSWM immediately created four special purpose committees: Old People's Welfare; Rural Life; Drama; and Music (Interim Report, 1947: 4). Early on, CSSWM remained grounded in the network of depression-era local women's clubs concentrated in Glamorgan and Carmarthenshire. The counterpart clubs for men were in decline. The Council coordinated the CABx network across Wales; central government funded the Bureaux.

Even before the war, the Welsh Council shared a 'partnership' vision of the voluntary-statutory relationship with NCSS. Before the war, SWMCSS had defined a spirit of 'Social Service' that spanned government institutions and voluntary effort. It animated 'the administration of local government and petty justice, the management of local hospitals and district nursing associations, the voluntary service of one's community in hundreds of ways, ... (SWMCSS Fourth Annual Report, 1937-38: 7). Its account is worth quoting at length: 
Social service is enterprise which proceeds from a concern for human needs and human disabilities and any action which, out of a welter of bad housing and poverty, unemployment and bad employment, inadequate provision of recreational and cultural facilities, seeks to create a "green and pleasant land" is its task and its definition. It begins where statutory provision stops short and it seeks, by example and experiment in meeting unrecognised social needs, to tweak the conscience of the State and gain, for that particular need, both recognition and provision. It recognises too that deficiencies in statutory provision are almost balanced by ignorance of, or inability to use, existing provision and it seeks, therefore to ensure a wider and fuller use of such provision as already exists for human well-being. This is Social Service - the mouthpiece of inarticulate social needs, the pioneer in their experimental provision and the propagandist of provision already made. (SWMCSS Fourth Annual Report, 1937-38: 7)

SWMCSS asked, with a rhetorical flourish, "who will deny that, in many different guises, it [Social Service] is of the essence of life in South Wales?' A '... wide field of endeavour' that is 'at once the basis and the aims of the Council itself.' (SWMCSS Fourth Annual Report, 1937-38: 7). No bright line distinguishes local government from voluntary action here; instead 'social service' seems to blur any boundary between them.

As Britain's programme of postwar social legislation was being developed, the newly minted CSSWM articulated new pressures on voluntarism, while maintaining the case for voluntary-statutory partnership:

There is a prevalent feeling that the increasing concern of the Central Government and of Local Authorities in the work of social reform, as shown in such measures as the Education Act, 1944, the National Health Act and National Insurance Act, will stifle voluntary action and make unnecessary the continued existence of voluntary organisations. To-day there are not wanting indications - the public statements of Ministers, in the actions of Local Authorities, and very recently in the trenchant challenge of Lord Beveridge's Report on "Voluntary Action" - that ... voluntary action must still be an important force in the life of this country, whether in its existing forms or in a more closely integrated form with stronger sanctions than were possible formerly.

... voluntary organisation co-operates with Government Departments, Local Authorities, Trusts, and at the same time call upon private benefaction and spirited voluntary service to achieve its ends. (CSSWM, Annual Report, 194748: 4)

A year later, CSSWM reiterated these sentiments before welcoming Lord Pakenham's June 1949 'deliberate, solemn and wholehearted assurance' on voluntary action (CSSWM 2 $2^{\text {nd }}$ Annual Report, 1948-49: 4). Pakenham was contributing to a House of Lords debate that CSSWM found 'heartening': it 'stir[red] every member of our Council like a tale told in a chimney side corner.' ( $2^{\text {nd }}$ Annual Report, 1948-49: In that debate, Pakenham rejected the notion that 'all welfare is to be provided by the State itself'. 
While it consolidated its structural position as a Wales-wide body, the Council's total money income fell every year from 1950-51 until 1957-58. Without taking inflation into account, the Council's annual income exceeded its 1950-51 level only in 1963-64. The CSSWM received financial support from local authorities, businesses (including banks) and local fundraising. Its women's clubs changed their focus towards local social and charitable action, providing a modest but steady CSSWM income-stream into the 1960 .

The 'welfare state' in the 1960 s and 7os: from expansion to crisis in Wales Rather than continuity with the 1940 s and 50s, the 1960 s and 70 os were characterised by significant change for both state and voluntary action. Voluntarism was marked by professionalisation and social activism (Berridge and Mold, 2011, Hilton et al., 2012: 25-28). NCSS experienced 'moving frontiers' (Brasnett, 1969: 231-289, Brenton, 1985: 38-39), and may even have been 'losing ground' (Davis Smith, 2019: 135-166) during the 1960 s.

The state's role was also being understood differently. Alongside Crosland (1956), from the mid-1950s John Saville (1957) and Dorothy Thompson (1957) developed a sustained analysis of the welfare state. But their use of the term did not mean it become the generic label for social provision at this stage; it had not yet comprehensively displaced the term 'social services' in public debate. That change seems to have occurred around the early 1960s. CSSWM first used the 'welfare state' phrase in its 1960-61 annual report:

Today it is a commonplace to say that within the Welfare State the need for voluntary service has not decreased, but, to what extent this truism is appreciated, is not clear. (1960-61 Annual Report: 5)

If NCSS was losing ground in London, in Wales CSSWM seems to have had in a more stable position. It sought to sustain its historic posture on the compatibility of voluntarism and statutory provision. These traditional objectives continued to animate the Council's work under new conditions. It elaborated the persistent problems that remained unsolved by the 'Welfare State': care work ('bearing the burden of a crippled relative'); loneliness and unwillingness to adapt to modern conditions; 'adolescent delinquency' and 'senseless vandalism'. Addressing them was the concern of 'Government Departments, Local Government, Religious Bodies, charities and voluntary organisations'. CSSWM had developed a clearer sense of its own particular role was 'to serve all these bodies by co-ordination, skilled advice and actual work.' (1960-61 Annual Report: 5-6). Revealingly, Council 'policy' was to take on the coordination role, rather than viewing itself as one of the organisations being coordinated. It aimed to 'adapt its structure to meet the new conditions of the Welfare State and to try and weld together the statutory and voluntary organisations in fields of common interest.'

When CSSWM Director Ivor Cassam first used the term, he projected the idea back across all 'the post war years' (Annual Report 1960-61: 6). His anachronistic use of the term - applying it to a time before it was generally adopted (Petersen and Petersen 2013; Wincott 2011, 2014) - is characteristic of welfare state discourse. Cassam returned to the Council's relationship with the welfare state in 1967. Again, his concern was that statutory social provision could drive out voluntarism. He argued that voluntary work was generally misunderstood and underplayed. In 'these 
days of the Welfare State' some people 'confidently predict the demise of the voluntary spirit'. But they:

'would probably be surprised to learn that, according to reliable sources, some 800 new organisations have sprung up since the War. Many of these have the origins in Wales and thus the task of the Council continues to grow' (1966-67 Annual Report: 11).

From the late 1950s CSSWM was preoccupied with an unsettled reform agenda emanating from Whitehall and Westminster. Major government committees addressed aspects of social policy, social research local government and social services. The Molony Committee reflected on Consumer Protection (CSSWM, 196162: 27-28; 1962-63: 28, 1963-64: 33), while the Heyworth Committee, established in 1963, considered social research (and led to the Social Science Research Council in 1965 - CSSWM, 1964-65: 12). Developments around for local government and personal social services across Britain were particularly significant. They had potential to transform the Council's context as well as the setting for voluntary action more generally. Social policy-focused reform of local authorities became something of a saga between the late 1950s and mid-1970s, especially for personal social services. The Local Government Act 1958 started a reform process through parallel Commissions for Wales and England. Sixteen years later new local authorities finally came into existence for Wales and England in 1974 (and CSSWM became the Council of Social Service for Wales - CSSW).

The Seebohm Committee on Local Authority Social Services, established in 1965, was nestled alongside local government reform. The meaning of 'social service' seemed to change from being general term, it became associated with a specific area of local government provision. Seebohm had major implications for voluntary social services, triggering anxiety in the Welsh Council which 'awaited' its report 'with much interest' (CSSWM 1966-67 Annual Report: 11). The 1968 Seebohm Report proposed unified local authority social service departments under a Director. Implementing Seebohm, the 1970 Local Authority Social Services Act directed new resources to local authority social services in England and Wales. New Directors of Social Services took post between January 1971 and April 1972.

Overall, between the late 1950 os and the mid-1970s local government in Wales was the subject of two commissions, a white paper and various reports, plus expansive changes to statutory personal social services. Each was expected to have "profound effects upon the field work of this Council and, in particularly, upon our associated bodies, Community and Rural Community Councils' (CSSWM 1966-67 Annual Report: 11). The Council was acutely sensitive about its relationship to various levels of statutory action. Yet the changes to local government - and how they were seen by the Council - are best seen as helping to entrench the welfare state idea, not its antithesis. Coming to a head just as the 'golden age' is usually thought to have ended, these developments challenge the standard narrative of an allegedly nation-statewide welfare state defined by a 'need not geography' philosophy (Bogdanor 2009: 252). Through these years, the welfare state increasingly extended into personal services - including what we would now call care provision. It did not oppose meeting needs 'geographically' (or place-based provision) and encompassed local authorities and voluntary action, rather than replacing them. 
As late as 1972, the Welsh Council seemed relatively sanguine about the changes. Cassam reported 'effective co-operation' with the new Departments of Social Services and described 'the privilege of addressing a meeting of Directors of Social Services' (CSSWM 1971-72 Annual Report: 8). For its 1971 'Jubilee' the Welsh Council celebrated the 'significant part' it played 'in our society', a society 'very different, especially in its affluence, to that which existed in the thirties in Wales' (CSSWM, 1971-72 Annual Report: 7). As Conservative Prime Minister, Heath placed renewed emphasis on voluntary work. Working with the Welsh Office, CSSWM anticipated 'definite decisions regarding the expansion' of its activities with 'central government support' (1971-72 Annual Report: 8).

The Council's optimism proved short-lived. In Wales, two broad structural factors combined with a particular contingency to cause its collapse. First, local government reorganisation - including the emergence of statutory local social services - proved more profoundly challenging than the Council initially recognised. The new local authorities were obliged to provide their own services. They had no tradition of funding the CSSW. Taken together, the consequence was the loss of a previously dependable income source for the Council. Second, the economic downturn after the 1973 Oil Crisis had a major impact on fundraising. Wynford Vaughan-Thomas, then CSSW Chair, described 'clouds ... gathering rapidly over the nation's economy', causing the Council to have 'a hard fight to find funds' (CSSW, 1973-74: 5). Third, the Council faced a contingent challenge and cost: finding new headquarters. As it moved from Cardiff to new purpose-build facilities at Caerphilly, Cassim reported: ... the past twelve months have been the most traumatic and unsettling in the history of the Council. Circumstances, mostly beyond its control, have affected its policy, work and staff in a devastating manner. (1974-75 Annual Report: 4)

It made five staff members redundant, including the Senior Community Development Officer and both Women's Organisers.

Crisis and voluntary action: the (devolved administrative) state to the rescue? The mid-1960s saw the creation of UK government territorial Secretary of State for Wales and then, in 1965, the Welsh Office. Initially, these changes had remarkably few consequences for the Council (1964-65: 8). By the mid-1970s they were to prove critically important, as the Welsh Office saved CSSW from possible extinction. Following significant ad hoc bailouts in 1973 and 1974, the Welsh Office pushed a basic reorganisation of the Council, a 'conversion' of its aims and structure (Hacker, Pierson, Thelen 2013). A root-and-branch review (the Iles Report 1975-76: 8) proposed changes that echoed earlier developments at NCSS. It triggered the separation of three major specialist Welsh voluntary organisations (The Committee for the Welfare of the Elderly, The Wales Council for the Disabled, The Council for Wales of Voluntary Youth Services) from CSSW (1976-77: 7, 17-20). Iles also criticised the CSSW's Executive Committee as 'far too unwieldy', leading to their enmass resignation (1976-77: 7).

Seven new Council aims were identified:

' 1 . ... the establishment of a pattern and a forum for the voluntary movement in Wales.

2. Work associated with the problems of employment and unemployment.

3 . Work on the promotion and study of volunteers. 
4. Work on the problem of poverty in Wales

5. Work involved in the regional and social funds of the E.E.C., insofar as they involve community life within Wales with particular reference to the economically and socially disadvantaged.

6. Work associated with the promotion of good practice, effective management and value for money in voluntary organisations.

7. Work associated with the implications of the devolution of power to a Welsh assembly' (CSSW 1976-77: 8).

Reforms of the 1970s detached the Council from its direct engagement in particular sectors of voluntary action in Wales. Its new purpose was overarching, and cut across economic, social and political aspects of Welsh society. In practice, over the following years, its relationship with the Welsh Office influenced the Council's work significantly. It grew rapidly, arguably in an unexpected direction, directly delivering employment-related services, contracted by the Welsh Office for Manpower Services Commission projects. Subsequently, in the early 1980s, the Council was reborn as the WCVA and turned away from this service delivery role. Looking back, the objectives set in 1977 seem remarkably prescient. Not achieved in the 1970 , political devolution eventually came at century's end. Perhaps reflecting the weakness of other aspects of Welsh civil society, WCVA then played a much more central role in Welsh devolution than its equivalents did in Northern Ireland and Scotland.

\section{Conclusions}

As conventionally viewed, postwar social legislation established a nation-wide British welfare state. From the late 1940 a sense of being displaced by a new 'statism' (Crosland 1952) hung over voluntary social action. Important areas of social provision - such as hospitals - were brought under public ownership, or 'nationalised'. However, the postwar British state did not take over the general governance of voluntary social action; voluntary actors maintained their presence throughout this period. Our analysis extends these findings to Wales. In the context of a relatively weak distinctive civil society institutions (Paterson and Wyn Jones 1999), the Welsh Council's resilience was striking.

Equally, our territorial analysis challenges the focus of previous research on British/UK-level institutions (Brenton 1985; Finlayson 1994). Attending to its substate dimension uncovers a previously largely unresearched set of voluntary action structures 'completed' shortly before Labour's postwar social reform legislation. The new structure proved resilient. It partly counter-balanced statutory reforms, which were presented as 'national' in scope. Though state reforms aimed at de-localising some policies, our analysis underscores continuities in the social service role - and self-conception - of voluntarism, particularly through its relationship to local government around the ideas of partnership and shared working. Initially voluntarism and local government seemed almost co-mingled, under a sustained rubric of partnership we see differentiation of voluntary action from local government through the 1950 s and 6os. Over this period the structure of local government and its place in social services remained unsettled/unresolved. Rather than drift or layering (Hacker 2005), by the late 1960s 'unsettlement' had come to characterise voluntary-local government relations. Our analysis ends with the CSSW facing a larger change - a more fundamental 'conversion' (Hacker, Pierson and Thelen 2013) of its aims and organization, brokered by the devolved administrative 
arm of the state. Partly due to economic pressures conventionally associated with the end of the golden age, we show this change was (also) driven by internal dynamics of the welfare and territorial state.

Beyond its particular empirical concerns, our analysis connects to broader analytical themes. Although the scope and limits of its 'national' character have been neglected, ironically the welfare state has played a disproportionate role in standard histories of postwar Britain. Edgerton has led this critique. He argues that British 'national histories' and historiography have 'tended to tell the story of the nation in terms of the rise of the welfare state', with 'British national history' 'focused on very particular elements standing in for the whole without this being explicit (for example, the welfare state for the state)' (2018: xxvi, 593). This 'story of state welfare' in Britain 'is encrusted with myths', but we 'no longer need to think with such clichés ...' (Edgerton 2018: 224, xxvii). Instead of social policy, Edgerton's analysis of the postwar arc of British nationalism bracketed by Edwardian and Thatcherite globalism, is tied to the UK state's self-positioning in the global economy.

There is, moveover, mounting evidence that the social institutions inaugurated by Labour were not created in the name of the welfare state, which seems to have been attached to social policy after 1949 (Wincott 2011; Petersen and Petersen 2013) The term seems to have gained currency during the 1950s; arguably it was generally adopted only in the 1960s (Petersen and Petersen 2013; Wincott 2014; Edgerton 2018: 375). Evidence from the Welsh Council lends support to the argument that the welfare state label only became firmly attached to social policy relatively late in the day.

Too often periodisation plays a shadowy historiographical role. Periods can easily appear as natural facts of history. Especially when a period is viewed as an 'age' or 'era', the temptation is to homogenise its history - to characterise an entire epoch with generalised abstraction - like the welfare state. They can come to stand for the 'zeitgeist of an era' (Esping-Andersen 1999). Attention is focused on the turning points, critical junctures or crises that mark the beginning and end of an era. The period itself tends to be viewed as stable, or perhaps marked by steady, incremental change. Epochal generalisations (Wincott 2013) can elide the complexity of historical configurations. They presume a unity about histories that contain sharply contradictory elements (here, related to territory and voluntarism). Rendered in generalised abstract form, an epochal periodisation can easily become misleading. Making the welfare state stand for an entire 'era' can occlude the particular histories of social policies - such as tendencies towards English public service centralisation before 1939 (Ansell and Lindvall 2020) or the continuing and changing role of local authorities and voluntary organisations after 1945. Periodisation can also generate fallacies of anachronism, such as projecting a later concept of the welfare state back into earlier moments of history.

For research purposes periodisation could - we think should - be used as an explicit analytical tool. Used reflexively, rather than as a pre-given natural fact of history, periodisation can avoid such traps as anachronism and casual epochal generalisation. Crisis-based and epochal frames embody implicit methodological conceptual and historiographical - predilections. Explicitly reflexive periodisation can be put gradualist and non-epochal approaches into conversation against and alongside, say, crisis-based analyses. They can create space for challenges to the 
statist and territorial assumptions that underpin the (still) standard periodisation and historiography of the British welfare state. Here, we hope to have made a modest contribution to this conceptually and methodologically expansive agenda.

Bibliography

Alcock, P. (2010) 'Building the Big Society: A New Policy environment for the Third

Sector in England' Voluntary Sector Review 1, 3, 381-91.

Alcock, P. (2012) 'New Policy spaces: the impact of Devolution on Third Sector Policy in the UK' Social Policy \& Administration 46, 2, 219-238.

Alber, J. (1995) 'A Framework for the Comparative Analysis of Social Services' Journal of European Social Policy 5, 2, 131-49.

Anderson, B. (1983) Imagined Communities: Reflections on the Origin and Spread of Nationalism London: Verso.

Ansell, B. and Lindvall. J. (2020) Inward Conquest: The Political Origins of Modern Public Services Cambridge: Cambridge University Press.

Berridge, V. and Mold, A. (2011) 'Professionalisation, new social movements and voluntary action in the 1960 s and 1970s' in M. Hilton and J. McKay (eds) The Ages of Voluntarism London: The British Academy 114-134.

Birrell, D. (2009) The Impact of Devolution on Social Policy Bristol: Policy Press.

Bogdanor, V (2009) The New British Constitution Oxford: Hart.

Brasnett, M. (1969) Voluntary Social Action London: NCSS.

Brenton, M. (1985) The Voluntary Sector in British Social Services London:

Longman.

Checkland, K., Harrison, S. Snow, S., McDermott, I., Coleman, A. (2012)

'Commissioning in the English National Health Service: What's the Problem?'

Journal of Social Policy 41, 3, 533-550.

Chernilo, D. (2007) A Social Theory of the Nation-State London: Routledge.

Crosland, C.A.R. (1952) The Transition from Capitalism, in R.H.S. Crossman (ed)

New Fabian Essays London: Turnstile Press, 33-68.

Davies, J. (2007) A History of Wales London: Penguin.

Davis Smith, J, (2019) 100 Years of NCVO and Voluntary Action: Idealists and

Realists Basingstoke: Palgrave Macmillan.

Day, G. (2002) Making Sense of Wales: A sociological perspective Cardiff:

University of Wales Press.

Deakin, N. and Davis Smith, J. (2011) 'Labour, charity and voluntary action: the myth of hostility' in M. Hilton and J. McKay (eds) The Ages of Voluntarism London:

The British Academy, , 69-93.

Edgerton, D. (2018) The Rise and Fall of the British Nation London: Allen Lane.

Esping-Andersen, G. (1999) Social foundations of postindustrial economies Oxford:

Oxford University Press.

Ferrera, M. (2005) The Boundaries of Welfare: European Integration and the New Spatial Politics of Social Protection Oxford: Oxford University Press.

Finlayson, G. (1994) Citizen, State, and Social Welfare in Britain 1830-1990, Oxford: Oxford University Press.

Hacker, J (2005) Policy Drift: The Hidden Politics of US Welfare State Retrenchment in W. Streeck and K. Thelen (eds) Beyond Continuity: Institutional Change in Advanced Political Economies Oxford: Oxford University Press, 40-82. 
Hacker, J., Pierson, P. and Thelen, K. (2013) 'Drift and Conversion: Hidden faces of institutional change', in J. Mahoney and K. Thelen (eds) Advances in ComparativeHistorical Analysis Cambridge: Cambridge University Press, 180-208.

Hall, K., Alcock, P. and Millar, R. (2012) 'Start Up and Sustainability: Marketisation and the Social Enterprise Investment Fund in England' Journal of Social Policy 41, 4, 733-749.

Hills, J. (1990) (ed) The State of Welfare: the welfare state in Britain since 1974 Oxford: Clarendon Press.

Hilton, M., Crowson, N., Mouhot, J-F. and McKay, J. (2012) A Historical Guide to NGOs in Britain: Charities, Civil Society and the Voluntary Sector since 1945 Basingstoke: Palgrave Macmillan.

Jeffery, C. and Wincott, D. (2010) 'The challenge of territorial politics: beyond methodological nationalism', in C. Hay (ed) New Directions in Political Science London: Palgrave Macmillan, 167-188.

Johnes, M. (2012) Wales since 1939 Manchester: Manchester University Press. Keating, M. (2009) 'Social citizenship, solidarity and welfare in regionalized and plurinational states' Citizenship Studies 13, 5, 501-513.

Kendall, J. Mohan, J., Brookes, N. and Yoon, Y. (2018) 'The English Voluntary Sector: how volunteering and policy climate perceptions matter' Journal of Social Policy 47, 4 759-82.

Lazar, N. (2019) Out of Joint: Power, Crises and the Rhetoric of Time New Haven: Yale University Press.

McEwen, N. (2006) Nationalism and the State: Welfare and Identity in Scotland and Quebec Brussels: Peter Lang.

Marshall, T.H. ([1950] 1992) 'Citizenship and Social Class' in T.H Marshall and T.

Bottomore Citizenship and Social Class, 1-51.

Mooney, G. and Scott, G. (2005) (eds) Exploring Social Policy in the 'New' Scotland Bristol: Policy Press.

Paterson, L. and Wyn Jones R. (1999) 'Does Civil Society Drive Constitutional Change?' in B. Taylor and K. Thomson Scotland and Wales: Nations Again? Cardiff: University of Wales Press, 169-197.

Petersen, K. and Petersen J-H. (2013) 'Confusion and divergence: origins and meanings of the term 'welfare state; in Germany and Britain 1840-1940' Journal of European Social Policy 23, 1, 37-51.

Powell, M. and Miller, R. (2014) 'Framing Privatisation in the English National Health Service' Journal of Social Policy 43, 3, 575-594.

Propper, C. Wilson, D. and Burgess, S., (2006) 'Extending Choice in English Health Care: The Implications of the Economic Evidence' Journal of Social Policy 35, 4, 537-557.

Royles, E. (2007) Revitalising Democracy: Devolution and Civil society in Wales Cardiff: University of Wales Press.

Sheaff, R. (2009) 'Medicine and Management in English Primary Care: A Shifting Balance of Power?' Journal of Social Policy 38, 4, 627-647.

Simpson, M. (2017) 'The Social Union after the Coalition: Devolution, Divergence and Convergence' The Journal of Social Policy 46, 2, 251-268.

Stevens, M., Glendinning, C., Jacobs, S. Moran, N. Challis, D., Manthorpe, J., Fernandez, J-1., Jones, K. Knapp, M. Netten, A, Wilberforce, M. 'Assessing the Role of Increasing Choice in English Social Care Services' Journal of Social Policy 40, 2, 257-274.

Stewart, J. (2003) 'The National Health Service in Scotland, 1947-74: Scottish or British?' Historical Research 76, 193, 389-410. 
Wincott, D. (2006) 'Social Policy and Social Citizenship: Britain's welfare states' Publius 36, 1, 169-88.

Wincott, D. (2011) 'Images of welfare in law and society: the British welfare state in comparative perspective' Journal of Law and Society 38, 3, 343-75.

Wincott, D. (2013) 'The (golden) age of the welfare state: interrogating a conventional wisdom' Public Administration 91, 4, 806-22.

Wincott, D. (2014) Original and imitated or elusive and limited? Towards a genealogy of the welfare state idea in Britain, in D. Beland and K. Petersen (eds) Analysing Social Policy Language Bristol: Policy Press, 127-141.

Wincott, D. (2020) Imagined Solidarities: Brexit, Welfare, States, Nations and the EU, in M. Donoghue and M. Kuisma (eds) Whither Social Rights in (Post-)Brexit Europe Berlin: Social Europe Publishing and the Friedrich Ebert Stiftung, 7-15, https://www.fes-london.org/fileadmin/user_upload/PDF_Whither-Social-Rightsin-Post-Brexit-Europe.pdf\# page $=14$.

Primary Sources

Annual Reports South Wales and Momouthshire Council for Social Services, 1934 to 1938, 1940

Council of Social Services for Wales and Monmouthshire

Interim Report, 1947

Annual Reports, $1947-48$ to $1972-1973$

Council of Social Services for Wales

Annual Reports1973-74 to 1979-80 